Abstracta Iranica Abstracta Iranica

Revue bibliographique pour le domaine irano-aryen

Volume 25 | 2004

Comptes rendus des publications de 2002

\title{
« Kirman, terre de turbulence ». Iran XXXVIII, 2000, pp. 33-48, pl. XIII-XX.
}

\section{Rika Gyselen}

\section{(2) OpenEdition \\ 12 Journals}

\section{Édition électronique}

URL : http://journals.openedition.org/abstractairanica/4372

ISSN : 1961-960X

\section{Éditeur :}

CNRS (UMR 7528 Mondes iraniens et indiens), Éditions de l'IFRI

Édition imprimée

Date de publication : 15 mai 2004

ISSN : 0240-8910

\section{Référence électronique}

Rika Gyselen, « « Kirman, terre de turbulence ». Iran XXXVIII, 2000, pp. 33-48, pl. XIII-XX. », Abstracta

Iranica [En ligne], Volume 25 | 2004, document 108, mis en ligne le 15 mars 2006, consulté le 25 septembre 2020. URL : http://journals.openedition.org/abstractairanica/4372

Ce document a été généré automatiquement le 25 septembre 2020.

Tous droits réservés 


\section{« Kirman, terre de turbulence ». Iran XXXVIII, 2000, pp. 33-48, pl. XIII-XX.}

\section{Rika Gyselen}

Comme le titre ne le dit pas, cet article est consacré à l'étude des monnaies arabosassanides des divers ateliers du Kirman émises au nom des gouverneurs arabes. Ces monnaies constituent une des rares sources primaires pour aborder l'histoire mouvementée du premier siècle de l'Islam dans cette région.

\section{INDEX}

Thèmes : 3.2.3. Séleucides, Parthes et Sassanides

\section{AUTEURS}

RIKA GYSELEN

CNRS - Paris 